\title{
FINANCING FOR SECONDARY SCHOOL EDUCATION: EVIDENCE FROM BHAKTAPUR DISTRICT OF NEPAL
}

\author{
Narendra Katuwal ${ }^{1}$ \\ ${ }^{1}$ Reader, Department of Economics Education, Tribhuwan University, Mahendra Ratna Campus, Kathmandu. \\ Puspa Lal Pokharel (PhD) ${ }^{2}$ \\ ${ }^{2}$ Reader, Central Department of Education, Tribhuwan University, Kritipur, Nepal \\ Basudev Khanal ${ }^{3}$
${ }^{3}$ Lecturer, Department of Economics Education, Tribhuwan University, Mahendra Ratna Campus, Kathmandu.
}

Article DOI: https://doi.org/10.36713/epra6102

\begin{abstract}
It is a common problem almost throughout the world that secondary education institutions are financially bottlenecked, thus, being compelled financially to manage themselves from their own sources and resources. This study aims to assess the overall status of secondary schooling in terms of financing and cost by exploring the (re) sources and trends of financing to secondary education in Bhaktapur district of Nepal. Lined with the objective, a questionnaire was administered to collect the primary data. Both public or governmentaided and private secondary schools making a total of 12.6 percent of the population were selected on the simple random basis for the survey. The comparison established that although the public schools were government-aided, the per-unit cost rate was much higher for them than for the private ones mainly because of the decreasing student enrolment rates at the former case but increasing student enrolment rates at the latter. It was also found that the total expenditure of the schools was primarily dominated by recurrent expenditure- below 79 percent and 89 percent respectively. It was also found that 20.5 percent of the expenditure was covered by the regular tuition fee in the former case whereas 99 percent of it was covered by the regular tuition fee in the latter case. Based on the findings, it has been recommended that, since the government fund alone would not be adequate to support the growing requirement of quality schooling, the institutions should seek the ways of promoting cost-sharing with the local government, communities and NGOs as partners.
\end{abstract}

KEYWORDS- private school, Public school, recurrent expenditure, secondary education,

\section{INTRODUCTION}

Modern education development began in Nepal in 1959, with the dawn of democratic government as the modern era, education was available only to the son to the aristocrats. Girls rarely received formal education (Adhikari, 2012). Ministry of education is responsible for the administration and supervision of school-level education, under the ministry of education; district education offices with which some four hundred schools supervisors are affiliated. Management committees control the Schools. There is the provision of school management committee (SMC) Education Act to manage and mobilize physical, financial and human resources, operate, monitor and supervise the school, Nepal has made considerable progress in secondary education in terms of the number of students enrolled in the past two decades. The literacy rate has increased only about 54 percent in 2001 (CBS, 2003). 
Since the quality of schooling received by the majority of the students has appeared lower than that in many other countries of South Asia region, the issue of increasing access to quality secondary education remains a formidable challenge to Nepal (World Bank, 2000). This problem will widen further in the coming years due to the following regions. First, the student populations at all levels of education have continued to expand mainly because of rapid population (2.24\%) growth of the country. Second, most parents in Nepal aspire at least to educate their children up to the secondary level to secure the possibility of stable wage employment. Finally, the government has shown its commitment to expand access to school education adopting various liberal policy measures since 1951 .

Most of the schools were established and financed by individual and communities with their charitable donation before 1951. After the National Education System Plan (NESP) in 1971, the government implemented clear-financial guidelines about grants to such schools. The NESP policy on financing secondary education continued until 1990. In the early 1990s, the government further introduced free secondary education. It was initiated in 1992 beginning from grade 6 and completed in 1996. On the one side, this policy successfully contributed to enlarge secondary enrolments, on the other side, it increased the financial burden on the schools and the state.

More resources to increase participation in secondary education can come from five main sources. First, the budgetary provision could increase and hence secondary schools investment would rise, the second resource allocation within the education budget might be redirected towards secondary schooling. These options show little prospect in increasing the school financing resources keeping pace with the demand for schooling until the economy achieves a higher sustained growth rate. Third existing public resources could be utilized by reducing unit costs through greater efficiency while maintaining or increasing quality to allow more participation. This option of reducing unit costs through greater efficiency of secondary schools becomes a critical issue financing of secondary education in the coming years (Coombs \& Hallack, 1987). Forth, new resources of financing could be identified through a bigger contribution from private and community sources outside the public budget. In the case of fourth opinions, the student unions, students group are against the raised school fee. Thus, there is neither any clear guideline on cost recovery measures nor are there any political and administrative supports. Consistently, public secondary schools are taking difficulties to recover the cost. Fifth, reliance on private school is another opinion in a state of expansion (Levin, 1995; Lewin \& Ciallods, 2001).

The fifth opinion seems to be a possible alternative. A modest may occur in the number of private schools at the secondary level if this happens there would be some savings for the public budget that can be used to improve participation and quality in public secondary schools. The above experiences have raised the issue and challenge that must be addressed while analysing the economics of educational investments. It is in this context that this comparative study of the financing of public and private secondary school has been undertaken. A few studies has been carried regarding the financial situation of higher secondary and secondary education in Nepal. Because of this, the study is designed to identity it with special references to the unit cost and costsharing pattern of secondary education. So it is obvious that the study becomes more significant when it analyses the sources, issues, cost-sharing patterns, perspectives of financing education as well as examines the problem and issues in the education of secondary schools. With reference to this, the study was carried out to answer the following research questions: What are the sources of revenue? What is the trend of financing? What is the perspective of financing secondary education? What is the per-unit cost of secondary education'?

\section{RELEVANT WORKS}

Denison (1962) concluded that there exist a sheer contribution of schools to economic progress. This conclusion attracted with attention in academic circles when he first carried his study on a group of 1949 males of 25 years of age or above and reckoned their mean income. The study revealed that the income of the schools directly correspond to the increase in the years completed by the students. He ascribed that the three-fifths of reported income differentials for the study group was due to the effect of additional education.

School finance means the process by which tax revenues and other resources are derived for establishing, operating elementary and secondary schools. It is referred to the process by which these resources are allocated to schools different geographical areas and of the types and level of education. Since school finance heavily relies on decisions such as who will be educated in fashion and the social commitments of a society, there is no overall model that provides the appropriate approach to financing schools for all situation (Leyin, 1995; Peacook \& Wiseman, 1966). It is further stated that direct and indirect funding resources are required for elementary and secondary schools. Direct resources included the cost of teachers, buildings, materials and equipment and so on. Then direct resources are the cost of efforts of students to undertake study and the time forgone by them which constituencies should pay the costs of these resources is quite important.

It is pertinent to explain different types of education benefits. Education confers psychic returns, public good benefits, community benefits and individual externalities (spill over) effect (Peacook \& Wiseman, 1966). Moreover, Wiseman agreed on much to the opinion as expressed by Friedman. His reasons for parent's decision 
on the schooling choice of their children were similar to Friedman's. He also wanted the curtailment of government intervention through the enforcement of contracts in education. He focused his discussion on several important issues of education such as the imperfect competition, local monopoly, necessary education up to minimum age and a minimum standard of education and so on (Wiseman, \& Friedman, I978).

The most commonly used measurement is the unit cost per student per year that is calculated by dividing the total expenditure per academic year by the number of students enrolled in a particular educational category. Unit cost refers to expenditure per student. A common pattern of unit cost is the long-term rising trend tor the same type and quality of education. Analysis can compute and compare the unit cost between rural and urban primary schools, primary and secondary schools, institutions of different sizes and various university departments (Coombs \& Hallak, 1987).

The modernization and expansion of secondary schools occurred only after the Nepal National Education Planning Commission (NNEPC) 1956 with its pioneering report. Several recommendations of the NNEPC were implemented which created a positive environment in the education sector. Thus, for the modernization and the growth of general secondary schools, it laid a foundation and the present configuration is attributed to the implementation of the NNEPC report. Although another education educational body, All Round National Educational Committee (ARNEC), was formed in 1961, it initiated nothing new in the field of secondary education. Therefore, the conceptual basis of NNEPC prevailed until the advent of the National Education Committee in1971. The National Education Committee prepared the National Education System Plan (NESP) adding a strong development thrust to the education system. Before it, education goals had not been clearly stated. Hence, this document in this front appeared as a significant achievement (IEES, 1988).

Similarly, the fundamental contribution of private schooling is meeting the market demand not satisfied by the public education system. From the point of view of public finance, the role of private sch0ol is important because it affects quality education in English medium without adding any financial burden to the government. They have also checked the outflow of national resources to abroad (NPC, 1992). Community financing of education has a long history in Nepal. Although the democratic government established in 1951 began assisting schools, education was initiated, managed, and financed at the local level till 1971 (Thapa, 1993).

The local community resources were substantially used for the development of secondary education in the pre- NESP years (before 1971). With the implementation of NESP and free secondary education, the government began assuming increased responsibility for financing secondary schools (EES, 1988; NSAC, 1998). Ultimately, the community share appeared as low as 5percent in 1990/91. Moreover, the institutional support to education development also appeared very late in Nepal. The School Leaving Examination Board was established in 1951(World Bank, 1994).

Private financing through user charge is a type of financing which is based on the fact that most governments have faced financial problems and their ability to do much about it is limited. Thus, it requires the replacement of uniform lower price policies by introducing different prices by type of service and by type of consumer. User charge policy proposes that at a higher level, user fees ought to be selectively raised. Higherlevel is justified because primary education exhibits the highest social profitability among the three levels of education Subsidies should be denied to services that have large private benefits and to services mostly consumed by high-income people (Psacharopoulos, 1993).

Private schools depend mainly on private funding in developing countries. In contrast, developed countries subsidise over a large proportion of total expenses. These subsidies are accompanied by student admission criteria and control over hiring and firing of teachers. On the other hand, public schools heavily rely on public expenditure to finance the institutional cost. They also draw resources from the household. Although private resources are costs not borne by the government, government planners do need to understand the magnitude of these private costs (James, 1995).

Public education expenditure changes over time due to both supply and demand factors. Demand factors include the growth rate of the national economy and the range of competing demands of other public services besides other things. On the other hand, supply factors include demographic changes and the importance of education for development (Tsang, 1995).

The republic of Korea achieves 100 percent enrolment rate at primary school, 95 percent for middle school and 88 percent for high school in 1991. The grant from the central government and tuition fees are the major sources of educational funding in South Korea. The private sector contributes a relatively marginal amount. The government collects education expenditure through tax revenues (Shin, 1995). In Malaysia, education is provided free of cost to all children. Ministry of Education provides funding for government school. The Ministry of Rural and National Development fund specific junior science colleges. Pupils pay nominal fees and needy and deserving students at primary and secondary levels are given tree textbooks, scholarship and loans (Aziz \& Maimunah, 1995). China formally committed itself to attain the goal of universalizing access to basic education with the nine-year compulsory education law in 1986. At present, virtually all school-age 
children from most city areas attend primary school and enrolment rates at junior secondary are high (Lewin \& Caillods, 2001)

In the context of Nepal, Government of Nepal formed a High-Level National Education Commission (HLNEC) in1997 with a view to giving appropriate direction to education system. The HLNEC submitted its report in 1998 that assessed achievements and identified issues of each education level besides making recommendations. The report identified some important achievements for secondary education, such as free education up to grade 10, the establishment of the secondary education project, curriculum change and increase in the size of school and student. Simultaneously, the report recognized access, efficiency, quality and financing as major issues of secondary education (URSA, 1998). The major programs of the Tenth Plan (2002-2007) were to raise the quality of and the access to the secondary education. The Plan has intended to raise the gross enrolment ratio to 65 percent at the lower secondary level and 45percent at the secondary level (NPC, 2002).

Government of Nepal currently has adopted a policy to transfer the management of public schools to the community in accordance with the norms and thrust of Education Act and Local self-government Act. The process of management transfer has been initiated in 2002/2003 and 616 schools had been transformed into the community to that date. However, the effort of the government to speed up the background of national insurgency has opposed it (Upadhyaya, 1985). The school size is an important determinant of cost per student. The size of secondary school with an average of 516 pupil in the public sector and with an average of 189 pupils in the private sector has suffered from diseconomies of scale (Shiwakoti, 2006).

\section{METHODS AND MATERIALS}

Descriptive analytical survey method was used in this study for the primary data collection. Secondary sources of data also were used. The secondary sources of data were utilized to explore financial trends, student's enrolment and the total budget of the different schools.

\subsection{Sample and Population of the Study}

Considering the data provided by the District Education Office, Bhaktapur in 2067, there are 35 public and 92 private secondary schools among them nearly 13 percent have been selected in this study.

Table- 1. Distribution of Sample population in Bhaktapur

\begin{tabular}{|c|c|c|}
\hline Types of School & Total Number & Sample \\
\hline Public Secondary & $35(100 \%)$ & $8(23 \%)$ \\
\hline Private Secondary & $92(100 \%)$ & $8(9.0 \%)$ \\
\hline Total & $127(100 \%)$ & $16(12.6 \%)$ \\
\hline
\end{tabular}

Source: District Education Office, 2011

The sample included 23 percent of them ( 8 out of 35) public secondary school and 9 percent ( 8 out of 92 ) of the private secondary school. Simple random sampling was used to collect primary data. Among the total population, 12.6 percent population was surveyed for this study. Based on the objectives of the study, a set of questionnaire was designed to collect data from public and private secondary schools from Bhaktapur. The school information survey prepared to generate information on key characters, source of income, fixed asset, fixed expenditure, school fees from the sample secondary schools. The data validation exercise was more rigorous. The collected data checked thoroughly every day during the survey. After the completion of the field survey, the data have been tabulated, income, expenditure and costs were estimated using percentage and ratios. The comparison of cost between public and private secondary schools was also computed through the estimation of educational cost functions.

\subsection{General Profile of the Sampled Secondary Schools}

Bhaktapur district is more urbanized and developed characteristics compared to other districts of the country. To know the present status of the sample secondary schools of Bhaktapur district, the study has covered 16 (8 schools each from public and private) secondary schools.

Some Basic Indicators: Bhaktapur is one of the districts of Kathmandu valley among three districts. The study area is located approximately 1331 meters in above sea Level and cover119 sq. k. m. of total area. 
Volume: 8| Issue: 1| January 2021

Table- 2. Some Basic Indicators

\begin{tabular}{|l|l|}
\hline Total Population & 225461 (census 2001) \\
\hline Gender Ratio & 103.74 \\
\hline Average Family Size & 5.47 \\
\hline Urban Population & $120294(53.35)$ \\
\hline Population Density (Per sq. km.) & 1894.63 \\
\hline Major Cast & Newar, Brahman, Chhetri, Tamang \\
\hline Religion & $\begin{array}{l}\text { Hindu89.87,Buddhist9.4,Muslim0.15,Christian0.35,Kirat0.18, } \\
\text { Others0.07 percent }\end{array}$ \\
\hline Total Literacy Rate & $70.57(2058$ B.S.) \\
\hline Male literacy & 70.57 \\
\hline Female literacy & 59.64 \\
\hline Total number of School & 1428 \\
\hline Total Number of teacher & 2205 \\
\hline
\end{tabular}

The study area has clustered as well as a dispersed settlement, the total population of the study area is 225461. Major ethnic groups are Newar (56.05\%), Chhetri (18.39\%), Brahmin (10.13\%), Tamang (6.549\%), Magar (1.61\%), others (7.29\%). Average family size is 5.47 members. The low percentage of old depending $(11.1 \%)$ indicates short life expectancy in the study area (CBS, 2001). According to population census 2001, the literacy rate is greater than 70 percent in the study area. The primary level population is 31.64 percent, lower secondary and secondary level population is 33.98 percent in the study area.

Pupil/Teacher Ratio: As shown in table, pubic school has a pupillteacher ratio of 20, which has appeared 17 for private school. Both the ratios stand much lower than the government fixed ratio (1able- 3). The pubic secondary school has 17 average sizes of students, and private secondary school average around 20 (Table- 3).

Table- 3: Pupil-Teacher Ratio and Trained and Untrained Teacher by School Type (Average of the year 2009/2010)

\begin{tabular}{|c|c|c|c|c|c|}
\hline & & \multicolumn{2}{|c|}{ Teacher } & \\
\hline School type & Pupil & Trained & Untrained & Total & Pupil /Teacher Ratio \\
\hline Public N=8 & 5020 & $163(65 \%)$ & $88(35 \%)$ & 251 & 20 \\
\hline Private N-8 & 2635 & $55(35 \%)$ & $100(65 \%)$ & 155 & 17 \\
\hline
\end{tabular}

Source: Field Survey. 2011

Those who have a degree in education of the required level of qualification is known as trained teachers. The government also trains teacher by offering a ten-month on-the-job training. There are relatively more trained teachers in public secondary school (65percent) compared to private secondary school (35\%). It implies that the government has not been successful in supplying trained teachers in relation to its demand (Table- 3).

Examination: All pupils who pass the qualifying test can appear in SLC examination. A pass of SLC examination means successful completion of secondary education qualifying for the entrance examination to higher education. The number of students who took the SLC and their pass percentage is given in the table. This table includes the regular students who have just completed grade10 plus the compartment students. But it excludes the exempted students who are the SLC repeaters in all subjects.

Table- 4. Results of SLC Examination by School Type (Average of the Year 2009 and 2010)

\begin{tabular}{|c|c|c|c|c|c|c|c|c|}
\hline $\begin{array}{c}\text { School } \\
\text { Type }\end{array}$ & $\begin{array}{c}\text { SLC } \\
\text { appeared }\end{array}$ & $\begin{array}{c}\text { Passed } \\
\text { Dist. }\end{array}$ & $\begin{array}{l}\text { Passed } \\
1^{\text {st }} \text { div. }\end{array}$ & $\begin{array}{l}\text { Passed } \\
2^{\text {nd }} \text { div. }\end{array}$ & $\begin{array}{l}\text { Passed } \\
3^{\text {rd div. }}\end{array}$ & $\begin{array}{l}\text { Passed } \\
\text { Compt. }\end{array}$ & $\begin{array}{c}\text { Total } \\
\text { Passed }\end{array}$ & $\%$ \\
\hline Public & 315 & 15 & 40 & 132 & 110 & 18 & 223 & 71 \\
\hline Private & 465 & 206 & 110 & 110 & 2 & 23 & 451 & 97 \\
\hline Total & 780 & 235 & 190 & 277 & 122 & 65 & 660 & 85 \\
\hline
\end{tabular}

Both types of school could be regarded as efficient in SLC exam since the average of the two sample year shows that approximately 70 percent of public school students and 97 percent of the private secondary school students have passed the SLC examination. Above table shows private secondary schools are more efficient being ahead by about 27 percent pass figure (Table 4). 


\section{RESULTS AND DISCUSSIONS}

\subsection{Source and Revenue of Private and Public School}

There are different resources of income. As presented in the table below government budget has been the important source of financing in public school. The private secondary school did not receive any grants in aid from the government and has been surviving on its fund. Income came from government grants-in-aid (68 $\%)$, parents $(20.5 \%)$ and school $(11.5 \%)$ for a public school. The income generated from school fee $(99 \%)$ is very high in the private school. The other sources are negligible for private secondary school. The different sources of income of public and private secondary school are also presented here (Table 5).

Table- 5. Source of income of Public and Private Secondary Schools (Average of the year 2009/2010

\begin{tabular}{|c|c|c|c|c|}
\hline \multirow{2}{*}{ Source of income } & \multicolumn{2}{|c|}{ Public Secondary N=8 } & \multicolumn{2}{c|}{ Private Secondary N=8 } \\
\cline { 2 - 5 } & Amount(Rs.) & $\mathbf{9}$ & Amount(Rs.) & $\mathbf{\%}$ \\
\hline Government Grants in-aid & 2091663 & 66.5 & 0 & 0 \\
\hline Income from local government & 9436.07 & 0.3 & 0 & 0 \\
\hline Income from parents and student & 644798.4 & 20.5 & 2757633 & 99.0 \\
\hline Internal resources & 361716.2 & 11.5 & 8356.5 & 0.3 \\
\hline NGOs & 6290.7 & 0.2 & 0 & 0 \\
\hline Others & 31453.5 & 1.0 & 19498.4 & 0.7 \\
\hline & 3145358 & 100 & 2785488 & 100 \\
\hline
\end{tabular}

Source: Field Survey, 2011

On the one hand, public secondary schools obtain 66.5 percent income from the government on the other private secondary schools did not receive any financial support from the government. Income from local government source seemed to be very low with for public secondary schools. Overall, this source contributed below percent to the annual income of a public secondary school. On the other side, the private school did not get any financial support from local government.

Secondary schools have collected various types of fees from parents. They were collecting tuition fee, annual fee and examination fee. This seemed cost-sharing approach at the secondary level. Tuition fees were not collected at the secondary level in public secondary schools after the fiscal year 1991/1992. The public secondary school raised the annual amount of fees in one instalment. Examination fee was raised at the time of examination. In the same way, private secondary schools have raised different types of fees. The common items were monthly tuition fees, examination fee, transport fee, game fee, library fee, lab fee, first aid fee, computer education fee, school maintenance fee and miscellaneous fees. These evidences show that fee structures were not uniform in both the public and private secondary schools of Bhaktapur district.

Unlike public secondary schools, fees have increased year by year in private secondary schools. In the private level of fees has started from Rs. 15450 for grade 6 and has reached up to Rs. 22250 for grade 10, perpupil per annum in an average of 2010. The level of school fee in private secondary schools is much greater than public secondary schools in 2006 and approximately 17.5 times greater in 2010. There is increasing trend of school fee pattern for succeeding grade in both types of schools. This source contributed 20.5 percent to the annual income of a public secondary school and 99 percent to the income of private secondary school.

Internal income from school came in terms of rent and interest. Interest earned from annual bank balance had also contributed as a source of income to the public secondary schools, INGOs and NGOs were involved in different construction work in 3 of the sample public secondary schools. This was not a significant source of income for secondary school.

In private and public secondary schools, income from other resources were found significantly lower. This category included largely the income received from the sale of tie and belt and examination centre charge, school journal and diary. This source appeared 1.0 and 0.7 percent for public and private secondary schools respectively.

Table 7 shows that each public secondary school generated the income of Rs.3145385 annually, whereas it appeared to be Rs.2785488 for private secondary schools. The income of public secondary schools exceeded the income of private secondary schools. The private secondary school received income from parents and internal resource whereas public secondary schools received income from central government, local government, parents, NGO's and other sources.

\subsection{Trends of Expenditure Patterns of Sample Schools}

Total expenditure of secondary school was divided into main headings i.e. capital expenditure and recurrent expenditure. The trend of expenditure in private and public secondary education for the period of five years from 2006 to 2010 is presented in table 8 . The total expenditure on schools was mainly dominated by 
recurrent expenditure. The recurrent expenditure is higher as compared to expenditure. Total cost is the total expenditure. The total cost of the secondary level was broken into total fixed cost and total variable cost (TVC) or total expenditure is divided into capital expenditure and recurrent expenditure.

Table -6. Trend of Capital and Recurrent Expenditure of the Past Five Years (2006-2010) (Rs. in '000')

\begin{tabular}{|l|c|c|c|c|c|c|}
\hline \multirow{2}{*}{ Year } & \multicolumn{3}{|c|}{ Public School } & \multicolumn{3}{c|}{ Private School } \\
\cline { 2 - 7 } & Total Exp. & $\begin{array}{c}\text { Capital } \\
\text { Exp. }\end{array}$ & $\begin{array}{c}\text { Recurrent } \\
\text { Exp. }\end{array}$ & Total Exp. & $\begin{array}{c}\text { Capital } \\
\text { Exp }\end{array}$ & $\begin{array}{c}\text { Recurrent } \\
\text { Exp. }\end{array}$ \\
\hline 2006 & 22160 & 3760 & 18400 & 16280 & 1600 & 14680 \\
& - & $(16.97)$ & $(83.03)$ & - & $(9.8)$ & $(90.2)$ \\
\hline 2007 & 23200 & 3600 & 19600 & 20160 & 20160 & 18000 \\
& $(4.48)$ & $(15.5)$ & $(84.5)$ & $(19.25)$ & $(10.7)$ & $(89.3)$ \\
\hline 2008 & 25400 & 5600 & 19800 & 28624 & 2624 & 2600 \\
& $(8.66)$ & $(22.05)$ & $(77.96)$ & $(29.56)$ & $(9.17)$ & $(90.83)$ \\
\hline 2009 & 40192 & 6440 & 33792 & 28160 & 2800 & 25360 \\
& $(36.8)$ & $(16.02)$ & $(83.38)$ & $(-1.65)$ & $(9.9)$ & $(90.11)$ \\
\hline 2010 & 45952 & 5320 & $(37512)$ & 36048 & 3328 & 35920 \\
& $(12.5)$ & $(11.58)$ & $(88.42)$ & $(21.88)$ & $(9.3)$ & $(90.7)$ \\
\hline Average & Growth rate & $(16.4)$ & $(83.6)$ & Growth rate & $(9.6)$ & $(90.4)$ \\
& $(15.61)$ & & & $(17.26)$ & & \\
\hline
\end{tabular}

Source: Field Survey, 2011

(Note: Parenthesis indicate percentage)

There is a disparity in the percentage of capital and recurring expenditure between the sample public and private secondary schools. The average recurrent expenditure in a private school is 90.4 percent whereas in public school recurrent expenditure is 83.6 percent. As shown in the table 6, total expenditure of sample secondary school 2006 was Rs. 22160 and Rs. 16280 which was increased to Rs. 45952 and Rs, 36048 thousand in 2010 leading to the average growth rate of 15.6 and 17.26 percent per year respectively. The salary expense was the most important portion of the total expenses, which grow a very high rate.

\subsection{Tends of Per Unit Expenditure of Sample Secondary School}

The unit cost per student was calculated by dividing the recurrent expenditure for each school by the total enrolment of each sample public and private school from 2006 to 2010. The table shows the average perunit income and expenditure for the past five years (Table 7).

Table- 7. Average per-unit Income, Expenditure and Number of Student, (2006-2010).

\begin{tabular}{|c|c|c|c|c|}
\hline \multirow{2}{*}{ Year } & \multicolumn{2}{|c|}{ Public Sec. School } & \multicolumn{2}{c|}{ Private Sec. School } \\
\cline { 2 - 5 } & Per unit rec. exp. & No. of Student & Per unit rec. exp. & No. of Student \\
\hline 2006 & 11219 & 1640 & 7978 & 1840 \\
\hline 2007 & 11666 & 1680 & 9183 & 1960 \\
\hline 2008 & 12958 & 1528 & 12745 & 2040 \\
\hline 2009 & 22498 & 1502 & 11962 & 2120 \\
\hline 2010 & 25763 & 1456 & 16629 & 2160 \\
\hline
\end{tabular}

In the above table per unit expenditure, of public and private secondary school from 2006 to 2010 has been depicted. As given in table public school per unit cost is the very high per-unit cost is due to the decreasing trend of student enrolment in those schools. The student enrolment in a private school is in increasing around whereas student enrolment in public school is in decreasing trend. The student enrolment private school is an increasing trend, whereas the student environment in public secondary school is in a decreasing trend (Table 7).

\section{CONCLUSIONS}

Among the various sources of income, government grant has been the most important source of financing for public secondary school but private secondary schools have survived from tuition fees generated from parents. For a private secondary school, income came almost exclusively from parents (99\%). For a public secondary school, income came from government grants $(66.5 \%)$, parents $(20.5 \%)$ and internal sources of school $(11.5 \%)$. The other sources are not significant. The only annual fee was mandatory in all sample public secondary schools. Private secondary schools completely relied on different forms of school fees including 
tuition fee, examination fee, transport fee, sports fee, library fee, lab fee, computer instruction fee, school maintenance fee etc. Private secondary schools varied in fee policy depending on the public demand for enrolment in their school. Overall, this source contributed 20.5 percent to the annual income of public secondary school but it appeared to contribute 99 percent to the income of private secondary school. Income from internal sources of school came in the form of rent and interest. This resource contributes 11.5 percent income to the annual income of public secondary school. Private secondary school generated only 0.3 percent of income annually. The income from local government, NGOs and other sources were very low in both types of schools.

Additionally, public secondary school per unit cost is very high compared to private secondary school. The main reason for the high per-unit cost is due to the decreasing trend of student enrolment in those schools. However, the student enrolment in a private school is in increasing trend. The private secondary education system appeared to be much more expensive than the public secondary school system.

Similarly, total expenditure of schools was primarily dominated by recurrent expenditure. Almost for the work five years from 2006 to 2010 the share of recurrent expenditure was less than 78 percent in public school whereas in private school it was 89 percent. It is clear that the total expenditure of public school was Rs. 22160 thousand in 2006 which was increased to Rs. 45952 thousand in 2010, leading to an average growth rate of 15.6 percent. However recurrent expenditure increased by 84 percent per year whereas the growth rate of capital expenditure increased by 16 percent per year. The total expenditure of private school was 96280 thousand in 2006, which was increased to Rs. 36048 thousand in 2010. Average growth was 17 percent. Average recurrent expenditure of private secondary school increased by 90 percent per year whereas the growth rate of capital expenditure of private secondary school increased by only 10 percent per year. The salary expense was the most important portion of the total expenses which grew at a very high rate.

There were three important sources of annual income for public secondary schools: government, parents and school's internal resources. Among them, the government budget had been the most important source of financing. In contrast to this, private secondary school did not receive any financial support from the government. The level of school fee in private secondary schools is much higher than public secondary schools.

\section{REFERENCES}

1. Adhikari, K. P. (2012). Financing of education. Kathmandu: Shuvakamana Prakashan.

2. Aziz, A.A. \& Maimunah. S. (1995). Malaysia: System of education. Husein, \&T. Postlethwaite, (Eds.). The international encyclopaedia of education (2nd ed., Vol. 6). London: PERGAMON.

3. Central Bureau of Statistics (CBS) (2010). District profile. Kathmandu: Author

4. Coombs. P. \& Hallak, J. (1987). Cost analysis of education: A tool for policy and planning. Baltimore: The John Hopkins University Press.

5. Psacharopoulos, G. (1994). Returns to investment in education: A global update. World Development, 22(9), 1325-1343.

6. Denisn, E. (1962). Education and growth, In C. Benson(Ed), Perspectives in the economics of education: Reading in school finance and business management (pp.55-41). Boston: Houghton Mifflin company.

7. IEES, (1988). Nepal education and human resources sector assessment. USA: Florida State University

8. Jimenez. E (1995). Financing public education Practices and trends, in T. Husen, T. Postlethwaite, (ds.). The International Encyclopaedia of Education (2nd ed., Vol. 4) London: PERGAMON

9. Lavin, H.M. (1995). School finance. In T. Husen, \& T. Postlethwaite, (Eds.).The international encyclopaedia of education (2nd ed., Vo. 9)Great Britain: PERGAMON

10. Lewin. K. \& Cavillods, F. (2001). Financing secondary education in developing countries: Strategies for sustainable growth. Paris: UNESCO Publishing.

11. Ministry of Finance (MOF) (2011). Economic survey 2010/11. Kathmandu: Author.

12. National Planning commission (NPC) (2002). The tenth plan 2002-2007.Kathmandu: Author.

13. National Education Commission (NEC) (1992). Report of the national education commission 1992. Kathmandu: Author.

14. Peacock, A. T., \& Wiseman, J. (1966). Economic growth and the principles of educational finance in developed countries. Financing of Education for Economic Growth, 89-101.

15. Psacharopoulos, G. (1994). Returns to investment in education: A global update. World Development, 22(9), 1325-1343.

16. Shin, S. (1995). Korea, System of education. In T. Husen\& T. Postlewaite (ED.). The international encyclopaedia of education (2nd ed.), GB: PERGAMON

17. Siwakoti, D.R, (2006). Financing Secondary Education in Nepal. PhD Thesis, Central Department of Economics, T.U., Kathmandu.

18. Tsang M. (199). Private and public cost of shooing in developing Nations. In Martin Carney (Ed.). The international encyclopaedia economies of education (2nd ed.), UK: PEROAMONU

19. Upadhyaya, I. P. (1984). Education planning in Nepal: Some observation. Paper presented at the T.U., Kathmandu.

20. URSA. (1998). Uchastaria Rastria Siksako Pratibedan 2055 (Report of the high-level national education commission 1999): Kathmandu: Author. 
EPRA International Journal of Environmental Economics, Commerce and Educational Management Journal DOI: 10.36713/epra0414 |ISI I.F Value: 0.815|SJIF Impact Factor (2020): 7.572

Volume: 8| Issue: 1| January 2021

21. Wiseman, ML Friedman, L., (1978). Understanding the equity consequences of school finance reform. Harvard Educational Review, 48(2), 1993-1994.

22. Word Bank (2001). World development report 2000/2001: Attacking poverty. New York. Oxford University Press. 